UNDERGRADUATE RESEARCH IN NATURAL AND CLINICAL SCIENCE AND TECHNOLOGY (URNCST) JOURNAL Read more URNCST Journal articles and submit your own today at: https://www.urncst.com

\title{
Cognitive Profiles Distinguishing Dementia Due to Alzheimer's Disease from Vascular and Lewy Body Dementia: A Literature Review
}

\author{
Muinat O. Baruwa, HBSc Student [1]*, Areem A. Siddiqi, HBSc Student [1], \\ Humaiyra Y. Patel, HBSc Student [1]
}

[1] Department of Psychology, University of Toronto Scarborough, Toronto, Ontario, Canada M1C 1A4

*Corresponding Author: muinat.baruwa@mail.utoronto.ca

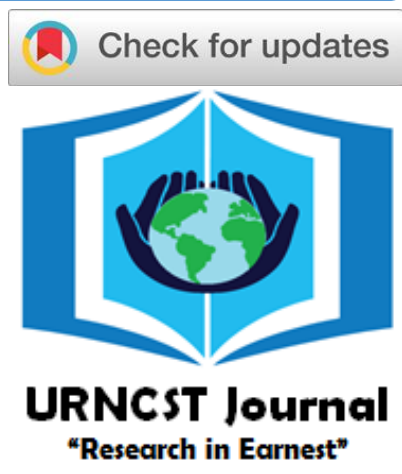

\begin{abstract}
Introduction: Diagnosing the etiology underlying dementia symptoms can be difficult because of the broad nature of shared cognitive impairments across dementia subtypes. Therefore, we sought to differentiate the cognitive profiles of Alzheimer's disease (AD) from vascular dementia (VaD) and Lewy body dementia (LBD).

Methods: PubMed, ScienceDirect, Web of Science, Google Scholar, and PsychINFO were searched for studies comparing the cognitive profile of $\mathrm{AD}$ to those of $\mathrm{VaD}$ and $\mathrm{LBD}$ along the domains of memory, language, and executive function.

Results: Short-term and episodic memory were more severely impaired in AD than in VaD and LBD. Semantic memory was more impaired in AD than LBD, but it was similarly impaired in AD and VaD. Semantic fluency was worse in AD than in $\mathrm{VaD}$, and phonemic fluency was worse in $\mathrm{AD}$ compared to $\mathrm{VaD}$ and $\mathrm{LBD}$. Naming was more impaired in $\mathrm{AD}$ compared to $\mathrm{VaD}$ and LBD. Executive function impairments were similar or less severe in AD relative to VaD and LBD.

Discussion: Findings may be explained through neuropathological correlates of each disease. Tau proteins targeting the medial temporal lobes and synaptic loss in prefrontal cortices in $\mathrm{AD}$ may explain greater memory deficits in $\mathrm{AD}$ relative to $\mathrm{VaD}$ and LBD. In those with AD, the temporal lobes undergo greater atrophy than in those with VaD and LBD, possibly contributing to the greater semantic fluency impairments in AD. Greater white matter loss in frontal lobes in $\mathrm{VaD}$ may be a reason for a worse phonemic fluency in $\mathrm{VaD}$ relative to $\mathrm{AD}$. Executive function impairments may be attributable to more deep white matter hyperintensities in those with $\mathrm{VaD}$ and more dopaminergic dysfunction of the basal ganglia in those with LBD relative to those with AD.

Conclusion: Understanding the cognitive profiles that differentiate AD from VaD and LBD would aid in more efficient and accurate diagnoses of dementia etiologies. Diagnoses could be further improved by using cognitive assessment in addition to neural and physiological measures. This knowledge may help identify individuals at risk of developing dementia, helping clinicians intervene early and prevent progression to severe stages.
\end{abstract}

Keywords: Alzheimer's disease; vascular dementia; Lewy body dementia; memory; language; executive function; executive functioning; attention

\section{Introduction}

As the proportion of older adults rises in many countries, so does the prevalence of dementia [1]. Dementia is a syndrome characterized by the progressive decline in cognitive abilities (such as memory, language, and executive function) to a degree that impacts one's ability to function independently [2]. The three most common causes of dementia are Alzheimer's disease (AD), vascular dementia ( $\mathrm{VaD}$ ) and Lewy body dementia (LBD) [3]. AD pathology is characterized by a loss of neurons and synapses [4], and this etiology accounts for up to $80 \%$ of all dementia cases [5]. This loss is due to the build-up of amyloid-beta $(\mathrm{A} \beta)$ proteins in the association areas of the brain and tau protein hyperphosphorylation in the medial temporal lobes and association areas [5-6]. AD progresses in three stages: preclinical AD, mild cognitive impairment (MCI), and AD dementia [7].

$\mathrm{VaD}$, the second most common cause of dementia [8], encompasses any vessel disorders that lead to cognitive decline. $\mathrm{VaD}$ can be divided into three subtypes: mixed dementia, in which $\mathrm{AD}$ and $\mathrm{VaD}$ both contribute to cognitive decline, post-stroke dementia, and subcortical $\mathrm{VaD}$ [9]. Unlike $\mathrm{AD}, \mathrm{VaD}$ has no defining marker for its pathology, as the vascular changes found in $\mathrm{VaD}$ can also be found in healthy older adults [10].

LBD is a type of dementia characterized by cortical and subcortical build-up of $\alpha$-synuclein proteins, which form Lewy bodies and $A \beta$ and tau proteins [11-12]. Subtypes of 
UNDERGRADUATE RESEARCH IN NATURAL AND CLINICAL SCIENCE AND TECHNOLOGY (URNCST) JOURNAL Read more URNCST Journal articles and submit your own today at: https://www.urncst.com

LBD, including Parkinson's disease dementia (PDD) and dementia with Lewy bodies (DLB), share many clinical features, such as cognitive, motor, and neuropsychiatric symptoms [13-14]. These symptoms differ in onset times; in PDD, motor impairments precede cognitive decline [13-14], but the opposite pattern is seen in DLB [13,15]. Cognitive impairments are commonly seen individuals with $\mathrm{AD}, \mathrm{VaD}$, and LBD. Therefore, it is important to distinguish between the three dementia etiologies, and this can be done using neuropsychological evaluations of the cognitive domains of memory, language, and executive function.

Memory is the ability to store and recall information [16], and can be measured by tasks such as the short-term memory (STM) binding task [17], in which participants study items and are tested in recall and recognition. Memory can be subdivided into implicit (i.e., outside our conscious awareness) and explicit (i.e., conscious) memory [18]. Explicit memory is further divided into episodic memory and semantic memory, which involve contextual recall of prior experience and recall of specific facts, respectively [19-20].

Studies examining language impairments in dementia have looked at oral verbal fluency as well as object naming. Verbal fluency, divided into phonemic and semantic fluency, involves retrieving information from memory [21-22] and is assessed based on the number of words generated in one minute [23]. Tests of phonemic fluency, such as the Controlled Oral Word Association Test (COWAT) [24], require participants to generate words that start with a given letter. Semantic fluency involves generation of words that fall under set categories [25], such as animals [26]. Word-retrieval impairments are commonly assessed using tasks such as the Boston Naming Test (BNT) [27] in which individuals name objects based on line drawings.

Executive function describes higher-order cognitive abilities that allow us to plan our actions, exhibit self-control, and adapt our behavior in unfamiliar situations [28-29]. Higher-order attention is an aspect of executive function that enables us to select and orient towards goalrelated stimuli and regulate our responses accordingly [29-30]. The different subtypes, including sustained, selective, and divided attention, can be assessed using tasks such as the Test of Everyday Attention (TEA) [31]. Another aspect of executive function is inhibitory control, a measure of distractibility often assessed using the Stroop task [29]. Other common assessments of executive function include the Clock Drawing Test (CDT) and the Wisconsin Card Sorting Task (WCST) [32].

Older adults with $\mathrm{VaD}$ or LBD are often misdiagnosed with $\mathrm{AD}$, leading to increased medical costs, which could be mitigated by an earlier and more informed diagnosis [33]. Varying degrees of cognitive deficits are commonly observed in different dementia subtypes. To help differentiate the cognitive profile of $\mathrm{AD}$ from those of $\mathrm{VaD}$ and LBD, this article aims to review the literature in neuropsychological performance that distinguishes these dementia etiologies along the cognitive domains of memory, language, and executive function.

\section{Methods}

Five electronic databases (PubMed, ScienceDirect, Web of Science, Google Scholar, and PsychINFO) were searched for studies in which the cognitive profiles of $\mathrm{AD}, \mathrm{VaD}$ and LBD were analyzed using neuropsychological tests. Search terms included "Alzheimer's disease", "Alzheimer's dementia", "vascular dementia", "Lewy body dementia", "Parkinson's disease dementia", "dementia with Lewy bodies", "memory" "explicit memory", "implicit memory", "short-term memory", "language", "semantic fluency", "verbal fluency", "executive function", "attention". The Boolean operators "and" and "or" were used to combine search terms. Inclusion criteria included (1) studies that compared $\mathrm{AD}$ to $\mathrm{VaD}$ or $\mathrm{LBD}$ along at least one of the three domains of interest using cognitive tests and (2) published between January 1990 and February 2020. Preprints were excluded. 41 studies were included in this review.

\section{Results \\ Memory \\ Alzheimer's Disease and Vascular Dementia}

$\mathrm{AD}$ showed a greater memory impairment overall compared to $\mathrm{VaD}$. One study found that older adults with $\mathrm{VaD}$ and $\mathrm{AD}$ scored lower on the Benton Visual Retention Test compared to healthy controls (HCs) [34]. Individuals with $\mathrm{AD}$ were found to perform significantly worse than those with $\mathrm{VaD}$ on STM tasks, such as the recall memory task (RMT) [34], Prose Memory test, and the STM Binding task [17]. In another study, participants with $\mathrm{VaD}$ performed better on tests of episodic memory compared to individuals with AD, but not as well as HCs [34]. Similar degrees of impairment in semantic memory measured by the CDT [35] and other semantic memory tests [36-37] were observed in $\mathrm{AD}$ and $\mathrm{VaD}$. No studies were found to have compared the differences in implicit and explicit memory between $\mathrm{AD}$ and $\mathrm{VaD}$.

\section{Alzheimer's Disease and Lewy Body Dementia}

Overall, prior research has shown that memory is more impaired in $\mathrm{AD}$ than LBD. Individuals with $\mathrm{AD}$ were found to perform significantly worse on the temporary memory binding (TMB) task compared to PDD and HC groups [38]. Relative to individuals with $\mathrm{AD}$, older adults with PDD performed better on STM tasks, including the RMT [39], the Prose Memory test, and the STM Binding task [17]. One study demonstrated that both AD and PDD groups showed similar levels of impairment on explicit memory tasks, such as the Bushchke Selective Reminding Test, relative to HCs [18]. Conversely, implicit memory was preserved in PDD [40] and AD, as measured using the Word-Stem Completion task and Maze Test [18]. Individuals with AD scored lower on the Five-Word Test, which measures episodic memory, compared to those with DLB [41]. Episodic memory 
UNDERGRADUATE RESEARCH IN NATURAL AND CLINICAL SCIENCE AND TECHNOLOGY (URNCST) JOURNAL Read more URNCST Journal articles and submit your own today at: https://www.urncst.com

consolidation was observed to be more severely impaired in AD than DLB [42]. On measures of semantic memory, those with AD performed worse than those with PDD [43].

\section{Language}

\section{Alzheimer's Disease and Vascular Dementia}

Individuals with dementia often demonstrate languagerelated deficits, such as impaired phonemic fluency, semantic fluency, and naming [44]. There have been mixed findings on the verbal fluency impairments in $\mathrm{AD}$ and $\mathrm{VaD}$. Semantic fluency was found to be more impaired in AD compared to $\mathrm{VaD}$ [45-46]. Some researchers [47-48] also found that individuals with $\mathrm{VaD}$ performed worse on phonemic fluency measures compared to those with AD, and HCs performed significantly better than the dementia groups. However, others found no significant differences in semantic [25,36,48-49] and phonemic fluency [25,45-46] between individuals with $\mathrm{AD}$ and those with $\mathrm{VaD}$. On the BNT, a test of naming, many researchers found that individuals with $\mathrm{AD}$ performed worse than those with $\mathrm{VaD}$ [34,46,49-50]. As expected, HCs outperformed both dementia groups on the BNT. Individuals with AD were generally found to have worse semantic fluency than phonemic fluency, whereas those with $\mathrm{VaD}$ tended to be more impaired in phonemic fluency $[45,47,51]$.

\section{Alzheimer's Disease and Lewy Body Dementia}

Studies investigating language impairments in LBD often distinguish DLB and PDD subtypes. Stern et. al [52] found that semantic fluency was less impaired in $\mathrm{AD}$ compared to PDD. However, most researchers found that semantic fluency is similarly impaired in AD compared to PDD [48,53-54] and DLB [22,26,55]. Phonemic fluency was found to be less impaired in AD relative to PDD [48] and DLB [26] as measured using the COWAT. Some researchers also found that participants with $\mathrm{AD}$ outperformed those with DLB [22,55] and PDD [52] on other phonemic fluency measures. However, others found that phonemic fluency was equally impaired in AD and PDD [53-54]. Individuals with $\mathrm{AD}$ were found to be more impaired than those with PDD [56] and DLB [57] on naming. Crowell et al. [26] found similar naming impairments in AD and DLB on the BNT.

\section{Attention and Executive function}

\section{Alzheimer's Disease and Vascular Dementia}

Studies comparing executive functioning in AD and $\mathrm{VaD}$ have found mixed results. On the TEA elevator counting task of sustained attention and Della Sala's dual task of divided attention, impairments were observed in $\mathrm{VaD}$, but not in $\mathrm{AD}$ [58]. $\mathrm{AD}$ and $\mathrm{VaD}$ were found to be equally impaired in sustained attention measured using the digit vigilance task [31]. Selective attention, measured using the map search and elevator counting with distraction tasks of the TEA, was observed to be more impaired in $\mathrm{VaD}$ than in $\mathrm{AD}$ [58]. Using the CDT, some researchers have found comparable degrees of impairment in executive function in both dementia groups [59-60], whereas others have found that individuals with $\mathrm{AD}$ outperformed those with $\mathrm{VaD}$ [35,61]. McGuiness et al. [31] found that both dementia groups were equally impaired on the Stroop task relative to HCs. However, Li et al. [62] found that individuals with VaD performed worse than individuals with AD on the Stroop task. Some studies have found similar impairments in the two dementia groups on the WCST relative to HCs $[58,63]$, whereas others have found greater impairments in $\mathrm{VaD}$ than AD [64-65].

\section{Alzheimer's Disease and Lewy Body Dementia}

Older adults with AD have usually been found to outperform those with LBD on executive functioning tasks. On the TEA elevator counting task, individuals with AD performed as well as HCs, but those with DLB performed worse than the other two groups [66-67]. Comparable impairments in selective attention, as measured using the TEA elevator counting with distraction task, were found between AD and DLB [66-67]. In contrast, as measured by the map search task, selective attention was found to be more impaired in DLB than in AD [66-67]. Divided attention was comparable in $\mathrm{AD}$ relative to $\mathrm{HCs}$, but it was impaired in DLB as measured using the Useful Field of View task [67] and Della Sala's dual task [66]. Calderon et al. [66] found that participants with $\mathrm{AD}$ performed significantly better than those with DLB on the Stroop task and the WCST. Park et al. [53] also found a lesser degree of impairment in individuals with $\mathrm{AD}$ relative to those with DLB using the Stroop task, whereas individuals with AD and PDD showed similar degrees of impairment. However, another study found no differences between AD and DLB groups on the Stroop task [68].

\section{Discussion}

Overall, studies suggested that episodic memory and STM were more impaired in AD than in LBD and VaD. Older adults with AD performed similarly to those with $\mathrm{VaD}$ on semantic memory tasks, but were more impaired compared to those with LBD. Implicit memory was found to be preserved in both LBD and AD. Semantic fluency was found to be similarly or more impaired in $\mathrm{AD}$ compared to $\mathrm{VaD}$. Greater impairments in phonemic fluency were found in $\mathrm{VaD}$ relative to $\mathrm{AD}$. Individuals with $\mathrm{AD}$ demonstrated similar impairments in semantic fluency, but less impairments in phonemic fluency relative to those with LBD. Naming was observed to be more impaired in AD compared to $\mathrm{VaD}$ and LBD. Although the results were mixed, the studies reviewed indicated that on average, $\mathrm{VaD}$ and LBD were associated with greater impairments relative to $\mathrm{AD}$ on measures of attention and executive function.

The findings of this review may be explained by the underlying neuropathology of each dementia subtype. Memory was found to be more severely impaired in individuals with $\mathrm{AD}$ compared to those with $\mathrm{VaD}$ and $\mathrm{LBD}$. The greater deficits in episodic and semantic memory in AD 
UNDERGRADUATE RESEARCH IN NATURAL AND CLINICAL SCIENCE AND TECHNOLOGY (URNCST) JOURNAL Read more URNCST Journal articles and submit your own today at: https://www.urncst.com

may be explained by the brain regions targeted by tau proteins. Specifically, these proteins target the medial temporal lobe regions, including the hippocampus [6,69-70]. Atrophy of the medial temporal lobe regions was also observed in $\mathrm{VaD}$ [71] and LBD [72], but to a greater extent in AD. The prefrontal cortex and sensory association areas involved in STM are affected in AD [4], which may explain the observed STM memory impairment.

Neuroimaging research provides insight into the different patterns of language impairments observed in dementia. Semantic fluency relies upon the temporal lobes, whereas phonemic fluency processes rely upon the frontal lobes [73]. Indeed, in their meta-analyses, Henry and Crawford [74] demonstrated that semantic fluency was more sensitive to temporal lobe lesions, and phonemic fluency was more sensitive to frontal lobe lesions. Similar levels of semantic fluency impairments have been seen in AD when compared to $\mathrm{VaD}$ and LBD. However, post-mortem magnetic resonance imaging (MRI) analysis showed higher medial temporal lobe atrophy in $\mathrm{AD}$ compared to $\mathrm{VaD}$ and LBD [72]. This MRI analysis does not explain the pattern of semantic fluency impairment observed in these dementia groups. Prior research has found more marked frontal lobe atrophy in LBD, supporting the finding of worse phonemic fluency in LBD compared to AD [75], but this finding was not supported by later research [76]. The neural mechanisms underlying naming have not been thoroughly investigated. Overall, the neuroimaging literature is inconclusive in differentiating between the three dementia etiologies. The inability of neuroimaging research alone to explain why different dementia etiologies lead to different patterns of impairments highlights the need for clinicians and researchers to use other physiological tests alongside neuroimaging. Future research should further investigate the neural underpinnings of verbal fluency and naming in the different dementia subtypes.

Impairments in executive function were demonstrated across three dementia groups, but the impairments were more substantial in $\mathrm{VaD}$ and $\mathrm{LBD}$ than in $\mathrm{AD}$. The observed deficits may be due to the dopaminergic dysfunction of the basal ganglia in LBD [77] that is not seen in AD [78], as the basal ganglia have been shown to guide attention [79]. The greater executive function deficits seen in $\mathrm{VaD}$ compared to $\mathrm{AD}$ may be partially attributable to white matter hyperintensities (WMH), which are associated with impairments on fronto-executive tasks [80]. Deep WMH, which are found in deep white matter, are more frequently seen in $\mathrm{VaD}$ than in $\mathrm{AD}$ [81]. In summary, the consensus of the literature appears to indicate lower performance on executive functioning tasks in individuals with LBD and $\mathrm{VaD}$ relative to those with $\mathrm{AD}$, which may be explained by the pathophysiology of the different dementia etiologies. Future studies could investigate the nature of the relationship between deep WMH and the different degrees of impairments of executive functions.

Baruwa et al. | URNCST Journal (2021): Volume 5, Issue 8

DOI Link: https://doi.org/10.26685/urncst.263
Identifying those who are at risk of developing dementia can help clinicians intervene early by beginning treatments and counseling. MCI, the stage between healthy aging and dementia, is characterized by some cognitive decline with relatively intact independent and occupational functioning [82]. Each of the reviewed dementia etiologies consists of prodromal MCI [83]. Clinical features, such as the severity of cognitive impairment and neuroimaging and fluid biomarkers, can predict the progression of MCI into AD dementia, but biomarkers for other MCI etiologies are less certain [82]. If the etiologies of MCI can be identified and symptoms are treated earlier, this could help prevent the onset of dementia, for which there are still no treatments available [84].

To maximize the efficiency and accuracy of AD, LBD, and $\mathrm{VaD}$ diagnoses, physiological and neuroimaging tests can be used in addition to neuropsychological tests. For example, cerebrospinal fluid concentrations of total tau protein, phosphorylated tau protein, and $A \beta 1-42$, can be combined to yield a classification accuracy above $85 \%$ between $\mathrm{VaD}, \mathrm{AD}$, and mixed dementia [85], as well as a sensitivity of $90 \%$ between LBD and AD [86]. Additionally, electroencephalography (EEG) has also been shown to be useful in discriminating between dementia etiologies [87]. A combined EEG and MRI model would also aid in differentiating $\mathrm{AD}$ from other dementia subtypes, as this method yielded a $90 \%$ classification accuracy between AD and DLB [88]. Combining cognitive assessments, physiological measures, and neuroimaging would allow for earlier, more accurate diagnoses of dementia subtypes, which could lead to more efficient development of interventions.

Differences in exclusion criteria varied across the studies we reviewed, which could affect the generalizability of our results. Although most studies used the consensus criteria for diagnosis of $\mathrm{AD}, \mathrm{VaD}$, and $\mathrm{LBD}$ [46], the exclusion criteria were not always uniform. Many authors excluded participants with psychotic disorders, history of substance abuse, and concurrent medication use [22,45,53], but not all authors confirmed the absence of vascular damage in participants with AD or LBD $[39,47,49]$. Therefore, some studies may have unknowingly included participants with mixed dementia instead of those with "pure" $\mathrm{AD}, \mathrm{VaD}$, or LBD. The variation in exclusion criteria could contribute to the lack of uniformity of the findings reviewed.

Future studies could consider comparing AD with other forms of dementia not reviewed in the present study (such as frontotemporal dementia) as well as mixed dementia. Additionally, other domains, such as visuospatial, logical reasoning, and psychiatric symptoms could also be compared between different dementia etiologies to provide a better understanding and diagnosis of neurodegenerative diseases. 
UNDERGRADUATE RESEARCH IN NATURAL AND CLINICAL SCIENCE AND TECHNOLOGY (URNCST) JOURNAL Read more URNCST Journal articles and submit your own today at: https://www.urncst.com

\section{Conclusions}

Cases of dementia will continue to rise as the population of older adults increases. Distinguishing between the cognitive profiles of different dementia subtypes, as done in this review, may allow for better understanding and management of dementia symptoms. Although some clear differences between $\mathrm{AD}, \mathrm{VaD}$, and $\mathrm{LBD}$ along the three domains of interest have been identified, there are many discrepancies between studies regarding the degrees of impairments in these subtypes. Therefore, to increase diagnostic efficiency and accuracy, cognitive assessments should be used in conjunction with neural and physiological tests.

List of Abbreviations Used

AD: Alzheimer's disease

VaD: vascular dementia

LBD: Lewy body dementia

A $\beta$ : amyloid-beta

MCI: mild cognitive impairment

PDD: Parkinson's disease dementia

DLB: dementia with Lewy bodies

STM: short-term memory

COWAT: controlled oral word association test

BNT: Boston naming test

TEA: test of everyday attention

CDT: clock drawing test

WCST: Wisconsin cart sorting task

HC: healthy control

RMT: recall memory task

TMB: temporary memory binding

MRI: magnetic resonance imaging

WMH: white matter hyperintensities

EEG: electroencephalography

\section{Conflicts of Interest}

The authors declare that they have no conflict of interests.

\section{Ethics Approval and/or Participant Consent}

Our study did not require ethics approval or participant consent as we conducted a review of the literature.

\section{Authors' Contributions}

MOB: Made substantial contributions to the drafting of the manuscript, revised the manuscript critically, and gave final approval of the version to be published.

AAS: Made substantial contributions to the drafting of the manuscript, revised the manuscript critically, and gave final approval of the version to be published.

HYP: Made substantial contributions to the drafting of the manuscript, revised the manuscript critically, and gave final approval of the version to be published.

\section{Acknowledgements}

We would like to express our utmost gratitude to Ricky Chow, whose guidance through every stage of writing this manuscript has been invaluable to us.

\section{Funding}

This study was not funded.

\section{References}

[1] Prince M, Bryce R, Albanese E, Wimo A, Ribeiro W, Ferri CP. The global prevalence of dementia: A systematic review and metaanalysis. Alzheimer's \& Dementia. 2013 Jan;9(1):63-75.e2. https://doi.org/ 10.1016/j.jalz.2012.11.007

[2] Arvanitakis Z, Shah RC, Bennett DA. Diagnosis and management of dementia: Review. JAMA. 2019 Oct;322(16):1589-1599. https://doi.org/10.1001/jama .2019 .4782

[3] Cunningham EL, McGuinness B, Herron B, Passmore AP. Dementia. Ulster Medical Journal. 2015 May;84(2):79-87.

[4] Karantzoulis S, Galvin JE. Distinguishing Alzheimer's disease from other major forms of dementia. Expert Review of Neurotherapeutics. 2011 Nov;11(11):15791591. https://doi.org/10.1586/ern.11.155

[5] Crous-Bou M, Minguillón C, Gramunt N, Molinuevo JL. Alzheimer's disease prevention: From risk factors to early intervention. Alzheimer's Research \& Therapy. 2017 Sept;9(71). https://doi.org/10.1186/s13195-0170297-Z

[6] Braak H, Braak E. Evolution of neuronal changes in the course of Alzheimer's disease. Journal of Neural Transmission. Supplementa. 1998;53:127-140. https://doi.org/10.1007/978-3-7091-6467-9_11

[7] Albert MS, DeKosky ST, Dickson D, Dubois B, Feldman HH, Fox NC, et al. The diagnosis of mild cognitive impairment due to Alzheimer's disease: Recommendations from the National Institute on Aging-Alzheimer's Association workgroups on diagnostic guidelines for Alzheimer's disease. Alzheimer's \& Dementia. 2011 May;7(3):270-279. https://doi.org/10.1016/j.jalz.2011.03.008

[8] O'Brien JT, Thomas A. Vascular dementia. The Lancet. 2015 Oct 24;386(10004):1698-1706. https://doi.org/10.1016/s0140-6736(15)00463-8

[9] Wallin A, Milos V, Sjögren M, Pantoni L, Erkinjuntti T. Classification and subtypes of vascular dementia. International Psychogeriatrics. 2003 Jul;15(S1):27-37. https://doi.org/10.1017/s1041610203008937

[10] Grinberg LT. Vascular dementia: Current concepts and nomenclature harmonization. Dementia \& Neuropsychologia. 2012 Sep;6(3):122-126. https://doi.org/10.1590/s1980-57642012dn06030002 
UNDERGRADUATE RESEARCH IN NATURAL AND CLINICAL SCIENCE AND TECHNOLOGY (URNCST) JOURNAL Read more URNCST Journal articles and submit your own today at: https://www.urncst.com

[11] Colom-Cadena M, Gelpi E, Charif S, Belbin O, Blesa $\mathrm{R}$, Martí MJ, et al. Confluence of $\alpha$-synuclein, tau, and $\beta$-amyloid pathologies in dementia with Lewy bodies. Journal of Neuropathology \& Experimental Neurology. 2013 Dec;72(12):1203-1212. https://doi.org/10.1097/ nen.0000000000000018

[12] Jellinger KA, Korczyn AD. Are dementia with Lewy bodies and Parkinson's disease dementia the same disease? BMC Medicine. 2018 Mar;16(1):34. https://doi.org/10.1186/s12916-018-1016-8

[13] Gomperts SN. Lewy body dementias: Dementia with Lewy bodies and Parkinson disease dementia. Continuum: Lifelong Learning in Neurology. 2016 Apr;22(2, Dementia):435-463. https://doi.org/10.1212/ con.0000000000000309

[14] Taylor JP, McKeith IG, Burn DJ, Boeve BF, Weintraub D, Bamford C, et al. New evidence on the management of Lewy body dementia. The Lancet Neurology. 2020 Feb;19(2):157-169. https://doi.org/ 10.1016/s1474-4422(19)30153-X

[15] McKeith IG, Boeve BF, Dickson DW, Halliday G, Taylor JP, Weintraub D, et al. Diagnosis and management of dementia with Lewy bodies: Fourth consensus report of the DLB Consortium. Neurology. 2017 Jul 4;89(1):88-100. https://doi.org/10.1212/ wnl.0000000000004058

[16]Zlotnik G, Vansintjan A. Memory: An extended definition. Frontiers in Psychology. 2019 Nov;10:2523. https://doi.org/10.3389/fpsyg.2019.02523

[17] Della Sala S, Parra MA, Fabi K, Luzzi S, Abrahams S. Short-term memory binding is impaired in AD but not in non-AD dementias. Neuropsychologia. 2012 Apr;50(5):833-840. https://doi.org/10.1016/j.neuropsy chologia.2012.01.018

[18] Kuzis G, Sabe L, Tiberti C, Merello M, Leiguarda R, Starkstein SE. Explicit and implicit learning in patients with Alzheimer disease and Parkinson disease with dementia. Neuropsychiatry, Neuropsycholology \& Behavioral Neurology. 1999 Oct;12(4):265-269. Available from: https://pubmed.ncbi.nlm.nih.gov/10527111/

[19] Tulving, E. Episodic and Semantic Memory. In Organization of memory. New York: Academic Press; 1972. p. 381-403.

[20] Niki C. Episodic-like semantic memory: Interaction between episodic and semantic memory in amnesia and semantic dementia. Japanese Psychological Review. 2008;51(1):138-147. Available from: https://psycnet.apa.org/record/2008-11931-007

[21] Lezak MD, Howieson DB, Loring DW, Hannay HJ, Fischer JS. Neuropsychological assessment. 4th ed. New York: Oxford University Press; 2004.
[22] Lambon Ralph MA, Powell J, Howard D, Whitworth AB, Garrard P, Hodges JR. Semantic memory is impaired in both dementia with Lewy bodies and dementia of Alzheimer's type: A comparative neuropsychological study and literature review. Journal of Neurology, Neurosurgery and Psychiatry. 2001 Feb;70(2):149-156. https://doi.org/10.1136/jnnp.70.2.149

[23] Mueller KD, Koscik RL, LaRue A, Clark LR, Hermann B, Johnson SC, et al. Verbal fluency and early memory decline: Results from the Wisconsin registry for Alzheimer's prevention. Archives of Clinical Neuropsychology. 2015 Aug;30(5):448-457. https://doi.org/10.1093/arclin/acv030

[24] Ivnik RJ, Malec JF, Smith GE, Tangalos EG, Petersen RC. Neuropsychological tests' norms above age 55: COWAT, BNT, MAE token, WRAT-R reading, AMNART, STROOP, TMT, and JLO. The Clinical Neuropsychologist. 1996 Jul;10(3):262-278. https://doi.org/10.1080/13854049608406689

[25] Barr A, Brandt J. Word-list generation deficits in dementia. Journal of Clinical and Experimental Neuropsychology. 1996 Dec;18(6):810-822. https://doi.org/10.1080/01688639608408304

[26] Crowell TA, Luis CA, Cox DE, Mullan M. Neuropsychological comparison of Alzheimer's disease and dementia with Lewy bodies. Dementia and Geriatric Cognitive Disorders. 2007;23(2):120-125. https://doi.org/10.1159/000097791

[27] Hobson VL, Hall JR, Harvey M, Cullum CM, Lacritz L, Massman PJ, et al. An examination of the Boston naming test: Calculation of "estimated" 60 -item score from 30- and 15-item scores in a cognitively impaired population. International Journal of Geriatric Psychiatry. 2011 Apr;26(4):351-355. https://doi.org/ $10.1002 /$ gps. 2533

[28] Gilbert SJ, Burgess PW. Executive function. Current Biology. 2008 Feb;18(3):R110-R114. https://doi.org/ 10.1016/j.cub.2007.12.014

[29] Diamond A. Executive functions. Annual Review of Psychology. 2013 Jan;64(1):135-168. https://doi.org/ 10.1146/annurev-psych-113011-143750

[30] Commodari E. Novice readers: The role of focused, selective, distributed and alternating attention at the first year of the academic curriculum. i-Perception. 2017 Aug;8(4):2041669517718557. https://doi.org/ $\underline{10.1177 / 2041669517718557}$

[31] McGuinness B, Barrett SL, Craig D, Lawson J, Passmore AP. Attention deficits in Alzheimer's disease and vascular dementia. Journal of Neurology, Neurosurgery and Psychiatry. 2010 Feb;81(2):157-159. https://doi.org/10.1136/jnnp.2008.164483

[32] Schroeder RW, Martin PK, Walling A. Neuropsychological Evaluations in Adults. American Family Physician. 2019 Jan;99(2):101-108. 
UNDERGRADUATE RESEARCH IN NATURAL AND CLINICAL SCIENCE AND TECHNOLOGY (URNCST) JOURNAL Read more URNCST Journal articles and submit your own today at: https://www.urncst.com

[33] Hunter CA, Kirson NY, Desai U, Cummings AKG, Faries DE, Birnbaum HG. Medical costs of Alzheimer's disease misdiagnosis among US Medicare beneficiaries. Alzheimer's \& Dementia. 2015 Aug;11(8):887-895. https://doi.org/10.1016/j.jalz.2015 .06 .1889

[34] Freitas MI, Porto CS, Oliveira MO, Brucki SM, Mansur LL, Nitrini R, et al. Linguistic abilities in major vascular cognitive impairment: A comparative study with Alzheimer's disease. Acta Neurologica Belgica. 2018 Sep;118(3):465-473. https://doi.org/ 10.1007/s13760-018-0977-x

[35] Allone C, Lo Buono V, Corallo F, Bonanno L, Palmeri R, Di Lorenzo G, et al. Cognitive impairment in Parkinson's disease, Alzheimer's dementia, and vascular dementia: The role of the clock-drawing test. Psychogeriatrics. 2018 Mar;18(2):123-131. https://doi.org/10.1111/psyg.12294

[36] Bentham PW, Jones S, Hodges JR. A comparison of semantic memory in vascular dementia and dementia of Alzheimer's type. International Journal of Geriatric Psychiatry. 1997 May;12(5):575-580. https://doi.org/ 10.1002/(sici)1099-1166(199705)12:5<575::aidgps566>3.0.co;2-n

[37] Vanderploeg RD, Yuspeh RL, Schinka JA. Differential episodic and semantic memory performance in Alzheimer's disease and vascular dementias. Journal of the International Neuropsychological Society. 2001 Jul;7(5):563-573. https://doi.org/10.1017/s1355617701 $\underline{75504 \mathrm{x}}$

[38] Kozlova I, Parra MA, Titova N, Gantman M, Sala SD. Alzheimer's disease and Parkinson dementia distinguished by cognitive marker. Archives of Clinical Neuropsychology. 2020 Feb: 1-9. https://doi.org/ 10.1093/arclin/acz082

[39] Phannarus H, Muangpaisan W, Siritipakorn P, Chotinaiwattarakul W. Cognitive profiles and optimal cut-offs for routine cognitive tests in elderly individuals with Parkinson's disease, Parkinson's disease dementia, Alzheimer's disease, and normal cognition. Psychogeriatrics. 2020 Jan;20(1):20-27. https://doi.org/10.1111/psyg.12451

[40] Appollonio I, Grafman J, Clark K, Nichelli P, Zeffiro $\mathrm{T}$, Hallett M. Implicit and explicit memory in patients with Parkinson's disease with and without dementia. Archives of Neurology. 1994 Apr;51(4):359367. https://doi.org/10.1001/archneur.1994.005401600 53008

[41] Economou A, Routsis C, Papageorgiou SG. Episodic memory in Alzheimer disease, frontotemporal dementia, and dementia with Lewy bodies/Parkinson disease dementia: Disentangling retrieval from consolidation. Alzheimer Disease \& Associated Disorders. 2016 Jan;30(1):47-52. https://doi.org/ $\underline{10.1097 / \mathrm{wad} .0000000000000089}$

Baruwa et al. | URNCST Journal (2021): Volume 5, Issue 8 DOI Link: https://doi.org/10.26685/urncst.263
[42] Hamilton JM, Salmon DP, Galasko D, Delis DC, Hansen LA, Masliah E, et al. A comparison of episodic memory deficits in neuropathologically-confirmed dementia with Lewy bodies and Alzheimer's disease. Journal of the International Neuropsychological Society. 2004 Sep;10(5):689-697. https://doi.org/ 10.1017/s1355617704105043

[43] Wieczorek D, Brockhuis B, Sitek EJ, Lass P, Wańska W, Sławek J. Memory impairment in dementia with Lewy bodies relative to Alzheimer's disease and Parkinson's disease with dementia. Acta Neuropsychologica. 2013;11(3):289-97. Available from:

https://actaneuropsychologica.com/resources/html/artic le/details?id=18972

[44] Kempler D, Goral M. Language and dementia: Neuropsychological aspects. Annual Review of Applied Linguistics. 2008 March;28:73-90. https://doi.org/10.1017/s0267190508080045

[45] Herbert V, Brookes RL, Markus HS, Morris RG. Verbal fluency in cerebral small vessel disease and Alzheimer's disease. Journal of the International Neuropsychological Society. 2014 Apr;20(4):413-421. https://doi.org/10.1017/S1355617714000101

[46] Braaten AJ, Parsons TD, McCue R, Sellers A, Burns WJ. Neurocognitive differential diagnosis of dementing diseases: Alzheimer's dementia, vascular dementia, frontotemporal dementia, and major depressive disorder. International Journal of Neuroscience. 2006 Jan;116(11):1271-1293. https://doi.org/10.1080/00207450600920928

[47] Canning SJD, Leach L, Stuss D, Ngo L, Black SE. Diagnostic utility of abbreviated fluency measures in Alzheimer disease and vascular dementia. Neurology. 2004 Feb;62(4):556-562. https://doi.org/10.1212/wnl .62 .4 .556

[48] Lim KB, Kim J, Lee HJ, Yoo J, Kim HS, Kim C, et al. COWAT performance of persons with Alzheimer dementia, vascular dementia, and Parkinson disease dementia according to stage of cognitive impairment. PM\&R. 2019 Jul;11(7):737-744. https://doi.org/ 10.1002/pmrj. 12125

[49] Villardita C. Alzheimer's disease compared with cerebrovascular dementia. Neuropsychological similarities and differences. Acta Neurologica Scandinavica. 1993 Apr;87(4):299-308. https://doi.org/ 10.1111/j.1600-0404.1993.tb05512.x

[50] Lukatela K, Malloy P, Jenkins M, Cohen R. The naming deficit in early Alzheimer's and vascular dementia. Neuropsychology. 1998;12(4):565-572. https://doi.org/10.1037/0894-4105.12.4.565

[51] Vuorinen E, Laine M, Rinne J. Common pattern of language impairment in vascular dementia and in Alzheimer disease. Alzheimer Disease and Associated Disorders. 2000 Apr;14(2):81-86. https://doi.org/ $\underline{10.1097 / 00002093-200004000-00005}$ 
UNDERGRADUATE RESEARCH IN NATURAL AND CLINICAL SCIENCE AND TECHNOLOGY (URNCST) JOURNAL Read more URNCST Journal articles and submit your own today at: https://www.urncst.com

[52] Stern Y, Richards M, Sano M, Mayeux R. Comparison of cognitive changes in patients with Alzheimer's and Parkinson's disease. Archives of Neurology. 1993 Oct;50(10):1040-1045. https://doi.org/10.1001/ archneur.1993.00540100035011

[53] Park KW, Kim HS, Cheon SM, Cha JK, Kim SH, Kim JW. Dementia with Lewy bodies versus Alzheimer's disease and Parkinson's disease dementia: A comparison of cognitive profiles. Journal of Clinical Neurology. 2011 Mar;7(1):19-24. https://doi.org/ 10.3988/jen.2011.7.1.19

[54] Suhr JA, Jones RD. Letter and semantic fluency in Alzheimer's, Huntington's, and Parkinson's dementias. Archives of Clinical Neuropsychology. 1998 Jul;13(5):447-454. https://doi.org/10.1093/arclin/13.5 .447

[55] Levy JA, Chelune GJ. Cognitive-behavioral profiles of neurodegenerative dementias: Beyond Alzheimer's disease. Journal of Geriatric Psychiatry and Neurology. 2007 Dec;20(4):227-238. https://doi.org/10.1177/ 0891988707308806

[56] Frank EM, McDade HL, Scott WK. Naming in dementia secondary to Parkinson's, Huntington's, and Alzheimer's diseases. Journal of Communication Disorders. 1996 May;29(3):183-197. https://doi.org/ 10.1177/0891988707308806

[57] Ferman TJ, Smith GE, Boeve BF, Graff-Radford NR, Lucas JA, Knopman DS, et al. Neuropsychological differentiation of dementia with Lewy bodies from normal aging and Alzheimer's disease. The Clinical Neuropsychologist. 2006 Dec;20(4):623-636. https://doi.org/10.1080/13854040500376831

[58] Graham NL, Emery T, Hodges JR. Distinctive cognitive profiles in Alzheimer's disease and subcortical vascular dementia. Journal of Neurology, Neurosurgery, and Psychiatry. 2004 Jan;75(1):61-71.

[59] McGuinness B, Barrett SL, Craig D, Lawson J, Passmore AP. Executive functioning in Alzheimer's disease and vascular dementia. International Journal of Geriatric Psychiatry. 2010 Jun;25(6):562-568. https://doi.org/10.1002/gps.2375

[60] Libon DJ, Malamut BL, Swenson R, Sands LP, Cloud BS. Further analyses of clock drawings among demented and nondemented older subjects. Archives of Clinical Neuropsychology 1996;11(3):193-205. https://doi.org/10.1016/0887-6177(95)00026-7

[61] Tiel C, Sudo FK, Calmon AB. Neuropsychiatric symptoms and executive function impairments in Alzheimer's disease and vascular dementia: The role of subcortical circuits. Dementia \& Neuropsychologia 2019 Sep;13(3):293-298. https://doi.org/10.1590/198057642018dn13-030005

Baruwa et al. | URNCST Journal (2021): Volume 5, Issue 8

DOI Link: https://doi.org/10.26685/urnest.263
[62] Li C, Zheng J, Wang J, Gui L. Comparison between Alzheimer's disease and subcortical vascular dementia: Attentional cortex study in functional magnetic resonance imaging. Journal of International Medical Research. 2011 Aug 1;39(4):1413-1419. https://doi.org/10.1177/147323001103900428

[63] Starkstein SE, Sabe L, Vázquez S, Tesón A, Petracca G, Chemerinski E, et al. Neuropsychological, psychiatric, and cerebral blood flow findings in vascular dementia and Alzheimer's disease. Stroke. 1996 Mar;27(3):408-414. https://doi.org/10.1161/ 01.STR.27.3.408

[64] Tei H, Miyazaki A, Iwata M, Osawa M, Nagata Y, Maruyama S. Early-stage Alzheimer's disease and multiple subcortical infarction with mild cognitive impairment: Neuropsychological comparison using an easily applicable test battery. Dementia and Geriatric Cognitive Disorders. 1997 Dec;8(6):355-358. https://doi.org/10.1159/000106655

[65] Padovani A, Di Piero V, Bragoni M, Iacoboni M, Gualdi GF, Lenzi GL. Patterns of neuropsychological impairment in mild dementia: A comparison between Alzheimer's disease and multi-infarct dementia. Acta Neurologica Scandinavica. 1995 Dec;92(6):433-442. https://doi.org/10.1111/j.1600-0404.1995.tb00477.x

[66] Calderon J, Perry R, Erzinclioglu S, Berrios G, Dening $\mathrm{T}$, Hodges J. Perception, attention, and working memory are disproportionately impaired in dementia with Lewy bodies compared with Alzheimer's disease. Journal of Neurology, Neurosurgery \& Psychiatry. 2001 Feb;70(2):157-164. https://doi.org/10.1136/ innp.70.2.157

[67] Yamin S, Stinchcombe A, Gagnon S. Comparing cognitive profiles of licensed drivers with mild Alzheimer's disease and mild dementia with Lewy bodies. International Journal of Alzheimer's Disease. 2016;2016:1-11. https://doi.org/10.1155/2016/6542962

[68] Breitve MH, Chwiszczuk LJ, Brønnick K, Hynninen MJ, Auestad BH, Aarsland D, et al. A longitudinal study of neurocognition in dementia with Lewy bodies compared to Alzheimer's disease. Frontiers Neurology. 2018 Mar;9:124. https://doi.org/10.3389/fneur.2018 .00124

[69] Berron D, van Westen D, Ossenkoppele R, Strandberg $\mathrm{O}$, Hansson O. Medial temporal lobe connectivity and its associations with cognition in early Alzheimer's disease. Brain A Journal of Neurology. 2020 Apr;143(4):1233-1248. https://doi.org/10.1093/brain/ awaa068

[70] Vonk JM, Bouteloup V, Mangin J, Dubois B, Blanc F, Gabelle A, et al. Semantic loss marks early Alzheimer's disease-related neurodegeneration in older adults without dementia. Alzheimer's \& Dementia: Diagnosis, Assessment \& Disease Monitoring. 2020 Aug;12(1):e12066. https://doi.org/10.1002/dad2.12066 
UNDERGRADUATE RESEARCH IN NATURAL AND CLINICAL SCIENCE AND TECHNOLOGY (URNCST) JOURNAL

Read more URNCST Journal articles and submit your own today at: https://www.urncst.com

[71] Kalaria RN. The pathology and pathophysiology of vascular dementia. Neuropharmacology. 2018 May;134(Pt B):226-239. https://doi.org/10.1016/ j.neuropharm.2017.12.030

[72] Burton EJ, Barber R, Mukaetova-Ladinska EB, Robson J, Perry RH, Jaros E, et al. Medial temporal lobe atrophy on MRI differentiates Alzheimer's disease from dementia with Lewy bodies and vascular cognitive impairment: A prospective study with pathological verification of diagnosis. Brain. 2009 Jan;132(1):195203. https://doi.org/10.1093/brain/awn298

[73]Jones S, Laukka EJ, Bäckman L. Differential verbal fluency deficits in the preclinical stages of Alzheimer's disease and vascular dementia. Cortex. 2006 Jan;42(3):347-355. https://doi.org/10.1016/s00109452(08)70361-7

[74] Henry JD, Crawford JR. A meta-analytic review of verbal fluency performance following focal cortical lesions. Neuropsychology. 2004 Apr;18(2):284-295. https://doi.org/10.1037/0894-4105.18.2.284

[75] Förstl H, Burns A, Luthert P, Cairns N, Levy R. The Lewy-body variant of Alzheimer's disease: Clinical and pathological findings. British Journal of Psychiatry. 1993 Mar;162(3):385-392. https://doi.org/ 10.1192/bjp.162.3.385

[76] Mak E, Su L, Williams GB, O'Brien JT. Neuroimaging characteristics of dementia with Lewy bodies. Alzheimer's Research \& Therapy. 2014;6(2):18. https://doi.org/10.1186/alzrt248

[77] McKeith I, O’Brien J, Walker Z, Tatsch K, Booij J, Darcourt J, et al. Sensitivity and specificity of dopamine transporter imaging with 123I-FP-CIT SPECT in dementia with Lewy bodies: A phase III, multicentre study. The Lancet Neurology. 2007 Apr;6(4):305-313. https://doi.org/10.1016/S14744422(07)70057-1

[78] Langlais PJ, Thal L, Hansen L, Galasko D, Alford M, Masliah E. Neurotransmitters in basal ganglia and cortex of Alzheimer's disease with and without Lewy bodies. Neurology. 1993 Oct;43(10):1927-1934. https://doi.org/10.1212/wnl.43.10.1927

[79] van Schouwenburg MR, den Ouden HE, Cools R. Selective attentional enhancement and inhibition of fronto-posterior connectivity by the basal ganglia during attention switching. Cerebral Cortex. 2015 Jun 1;25(6):1527-1534. https://doi.org/10.1093/cercor/ bht345
[80] Sudo FK, Alves CEO, Alves GS, Ericeira-Valente L, Tiel C, Moreira DM, et al. White matter hyperintensities, executive function and global cognitive performance in vascular mild cognitive impairment. Arquivos de Neuro-Psiquiatria. 2013 Jul;71(7):431-436. http://dx.doi.org/10.1590/0004282X20130057

[81] Smith CD, Johnson ES, Van Eldik LJ, Jicha GA, Schmitt FA, Nelson PT, et al. Peripheral (deep) but not periventricular MRI white matter hyperintensities are increased in clinical vascular dementia compared to Alzheimer's disease. Brain and Behavior. 2016 Feb;6(3):e00438. https://doi.org/10.1002/brb3.438

[82] Langa KM, Levine DA. The diagnosis and management of mild cognitive impairment: A clinical review. JAMA. 2014 Dec;312(23):2551-2561. https://doi.org/10.1001/jama.2014.13806

[83] Taragano FE, Allegri RF, Lyketsos C. Mild behavioral impairment: A prodromal stage of dementia. Dementia \& Neuropsychologia. 2008 Dec;2(4):256-260. https://doi.org/10.1590/S1980-57642009DN20400004

[84] Petersen RC. Mild cognitive impairment. Continuum: Lifelong Learning in Neurology. 2016 Apr;22(2 Dementia):404-418. https://doi.org/10.1212/CON.000 0000000000313

[85] Paraskevas GP, Kapaki E, Papageorgiou SG, Kalfakis N, Andreadou E, Zalonis I, et al. CSF biomarker profile and diagnostic value in vascular dementia. European Journal of Neurology. 2009;16(2):205-211. https://doi.org/10.1111/j.1468-1331.2008.02387.x

[86] Aerts MB, Esselink RA, Claassen JA, Abdo WF, Bloem BR, Verbeek MM. CSF tau, A $\beta 42$, and MHPG differentiate dementia with Lewy bodies from Alzheimer's disease. Journal of Alzheimer's Disease. 2011;27(2):377-384. https://doi.org/10.3233/JAD2011-110482

[87] Al-Qazzaz NK, Ali SH, Ahmad SA, Chellappan K, Islam MS, Escudero J. Role of EEG as biomarker in the early detection and classification of dementia. The Scientific World Journal. 2014;2014:1-16. https://doi.org/10.1155/2014/906038

[88] Colloby SJ, Cromarty RA, Peraza LR, Johnsen K, Jóhannesson G, Bonanni L, et al. Multimodal EEGMRI in the differential diagnosis of Alzheimer's disease and dementia with Lewy bodies. Journal of Psychiatric Research. 2016 Jul;78:48-55. https://doi.org/10.1016/j.jpsychires.2016.03.010 
UNDERGRADUATE RESEARCH IN NATURAL AND CLINICAL SCIENCE AND TECHNOLOGY (URNCST) JOURNAL Read more URNCST Journal articles and submit your own today at: https://www.urncst.com

\section{Article Information}

Managing Editor: Jeremy Y. Ng

Peer Reviewers: Ricky Chow, Bi-ru Amy Yeung

Article Dates: Received Apr 03 21; Accepted Jul 20 21; Published Aug 1321

\section{Citation}

Please cite this article as follows:

Baruwa MO, Siddiqi AA, Patel HY. Cognitive profiles distinguishing dementia due to Alzheimer's disease from vascular and Lewy body dementia: A literature review. URNCST Journal. 2021 Aug 13: 5(8).

https://urncst.com/index.php/urncst/article/view/263

DOI Link: https://doi.org/10.26685/urncst.263

\section{Copyright}

(c) Muinat O. Baruwa, Areem A. Siddiqi, Humaiyra Y. Patel. (2021). Published first in the Undergraduate Research in Natural and Clinical Science and Technology (URNCST) Journal. This is an open access article distributed under the terms of the Creative Commons Attribution License (https://creativecommons.org/licenses/by/4.0/), which permits unrestricted use, distribution, and reproduction in any medium, provided the original work, first published in the Undergraduate Research in Natural and Clinical Science and Technology (URNCST) Journal, is properly cited. The complete bibliographic information, a link to the original publication on http://www.urncst.com, as well as this copyright and license information must be included.
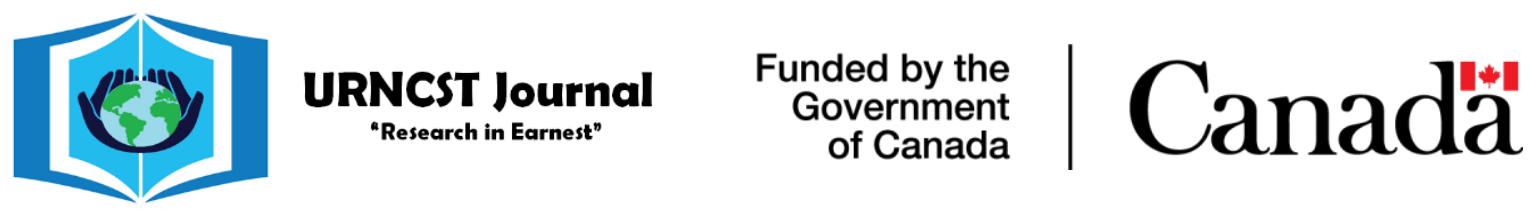

Do you research in earnest? Submit your next undergraduate research article to the URNCST Journal!

| Open Access | Peer-Reviewed | Rapid Turnaround Time | International | | Broad and Multidisciplinary | Indexed | Innovative | Social Media Promoted |

Pre-submission inquiries? Send us an email at info@ urncst.com | Facebook, Twitter and LinkedIn: @URNCST

Submit YOUR manuscript today at https://www.urncst.com! 